Ritrýnd grein birt 31. desember 2020

\title{
Kófið og leikskólinn: „Petta var mögnuð „tilraun“ til að sjá gæðastarf verða til við skrítnar aðstæður“
} Ingibjörg Ósk Sigurðardóttir og Svava Björg Mörk

Abstract Um höfunda $\quad \longrightarrow$ About the authors Heimildir

Leikskólastarf getur verið eins ólíkt á milli leikskóla og peir eru margir, enda stjórnast dagskipulag hvers leikskóla af áherslum og sýn peirra er par starfa. Sýn starfsfólks á nám og börn endurspeglar áherslur peirra í starfi. Nýlegar rannsóknir benda á að pað sé mikilvægt að hafa jafnvægi á milli athafna sem stýrt er af starfsfólki og athafna sem börnin stýra. Í pessu samhengi er einnig mikilvægt að taka tillit til parfa og áhuga hvers barns pegar skipuleggja á leikskólastarfið. Jafnframt parf að taka mið af réttindum barna og gefa peim tækifæri til að hafa áhrif á nám sitt.

Markmið rannsóknarinnar sem hér er sagt frá var að skoða áhrif takmarkana á leikskólastarf vegna fyrstu bylgju COVID-19 faraldursins, á leik barna og hlutverk leikskólakennara og annars starfsfólks. Jafnframt að skoða hvaða lærdóm mætti draga af reynslunni af takmörkununum. Gögnum var safnað með blönduðum aðferðum (e. mixed methods), annars vegar í gegnum einstaklingsviðtöl við leikskólastjóra og deildarstjóra, og hins vegar í gegnum spurningalista sem voru sendir út til 248 leikskóla um allt land.

Niðurstöður benda til pess að takmarkanirnar hafi haft töluverð áhrif á leikskólastarf í landinu. Stjórnendur töldu að starfið hefði einkennst af meiri gæðum. Peir töldu einnig að áhrif takmarkana hefðu skilað sér í aukinni velliððan barna og fullorðinna. Takmarkanirnar urðu pó til pess að skerða purfti aðgengi barnanna að leikefni. Pó að stjórnendur nefndu að ný vinatengsl hefðu myndast í barnahópnum pá kom einnig fram að einhver börn söknuðu vina sinna pegar takmörkun var á viðveru barnanna. Einhverjir starfsmenn upplifðu einnig einmanaleika par sem samgangur á milli peirra var takmarkaður. Rannsóknin er mikilvægt framlag til leikskólasamfélagsins og eykur skilning á peim áhrifum sem takmarkanir á skólastarfi vegna fyrstu bylgju COVID-19 höfðu á leikskólastarf. Niðurstöðurnar benda til pess að mikilvægt sé að rýna í skipulag og starfshætti leikskóla landsins og huga að hvernig hægt sé að tryggja gæðastarf með leikskólabörnum.

Efnisorð: COVID-19, leikskólastarf, leikur, hlutverk leikskólakennara, gæðastarf

\section{Inngangur}

COVID-19 faraldurinn hefur haft mikil áhrif á heiminn og par á meðal íslenskt samfélag. Leikskólastarf í landinu er par ekki undanskilið. Í fyrstu bylgju COVID-19, vorið 2020, var sett á samkomubann hér á landi pann 16. mars. Í kjölfarið urðu takmarkanir á skólahaldi í landinu sem meðal annars röskuðu leikskólastarfi töluvert. Samkvæmt minnisblaði frá sóttvarnalækni til heilbrigðisráðherra dagsettu 12. mars 2020 er lagt til að leikskólar skuli vera lokaðir að hluta og að ekki verði fleiri en 15 börn saman á hverjum tíma. Auk pess eigi að tryggja tveggja metra fjarlægð milli einstaklinga og að hreinlætisaðgerðum verði fylgt (Stjórnarráð Íslands, 2020). Pann 13. mars 2020 var jafnframt birt auglýsing um takmörkun á skólastarfi (nr. 216/2020) og í 3. grein hennar er fjallað um leikskólastarf. Par er eftirfarandi tekið fram: 
Leikskólum er heimilt, samkvæmt nánari ákvörðun sveitarfélaga, að halda uppi leikskólastarfi að peim skilyrðum uppfylltum að börn séu í sem minnstum hópum og aðskilin eins og kostur er. Jafnframt skulu gerðar ráðstafanir til að prífa eða sótthreinsa byggingar eftir hvern dag.

Takmarkanirnar urðu til pess að starf leikskóla breyttist töluvert. Pað var að miklu leyti í höndum hvers sveitarfélags að útfæra með hvaða hætti starfið var skipulagt í takt við takmarkanirnar. Pessir fordæmalausu tímar kölluðu á fordæmalausar ráðstafanir. Viðverudagar barnanna voru skertir í mörgum leikskólum, í öðrum var viðverutími peirra skertur og töluvert var um að leikskólarnir störfuðu með skertan mannafla.

Áhugi okkar á viðfangsefninu kviknaði eftir samtal við nemendur í leikskólakennaranámi við Menntavísindasvið Háskóla Íslands, par sem peir lýstu upplifunum sínum af breytingum sem urðu á starfinu í leikskólanum. Peir lýstu hvernig peirra eigið hlutverk breyttist og hvernig leikur barnanna og líðan breyttist sömuleiðis. Upplifanir peirra sýndu fram á mikilvægi pess að skoða pessar sérstöku aðstæður enn betur.

Markmið pessarar rannsóknar er að skoða áhrif takmarkana á leikskólastarf vegna COVID-19 faraldursins, á leik barna og hlutverk leikskólakennara og annars starfsfólks. Jafnframt að skoða hvaða lærdóm megi draga af reynslunni af takmörkununum. Gögnum var safnað með spurningakönnun sem send var til leikskóla landsins og einnig með viðtölum við leikskólastjóra og deildarstjóra. Spurt var hvaða áhrif samkomubannið hafði á leik barna og hlutverk peirra sem starfa með börnunum.

Rannsóknarspurningarnar sem leiddu rannsóknina voru eftirfarandi:

- Hvaða áhrif höfðu takmarkanir í leikskólastarfi vegna fyrstu bylgju COVID-19 á leik barna?

- Hvaða áhrif höfu takmarkanir í leikskólastarfi vegna fyrstu bylgju COVID-19 á hlutverk leikskólakennara og annars starfsfólks?

- Hvaða lærdóm má draga af reynslunni af takmörkunum í leikskólastarfi vegna fyrstu bylgju COVID-19 og áhrifum peirra á leikskólastarf?

\section{Fræðilegur bakgrunnur}

Í rannsókninni er stuðst við hugmyndir sampættra námskráa og kennslufræði leikskóla par sem áhersla er á sveigjanlegt skipulag og áhugasvið barnanna (Wood, 2013). Fjallað er um gæði í leikskólastarfi, leikinn sem námsleið ungra barna og hlutverk leikskólakennara.

\section{Gæði í leikskólastarfi}

Í sameiginlegum hluta fyrir aðalnámskrár leik-, grunn- og framhaldsskóla segir að „,[g]æði menntunar og árangur skólakerfisins byggist fyrst og síðast á vel menntaðri og áhugasamri fagstétt kennara á öllum skólastigum“ (Mennta- og menningarmálaráðuneytið, 2011, bls. 8). Rannsóknir sýna að gæðastarf í leikskólum hefur jákvæð áhrif á vellíðan og alhliða proska barna. Gæði hafa einnig áhrif á samskiptafærni barnanna og tungumálafærni auk pess sem gæðastarf hefur greinileg jákvæð áhrif á nám seinna meir (Campbell o.fl., 2012; Sylva o.fl., 2004; Vandell og Wolfe, 2000).

Fjölmargar rannsóknir hafa verið gerðar á gæðum í leikskólastarfi (sjá t.d. Sheridan og PramlingSamuelsson, 2013) og hafa Barnett og Frede (2010) dregið saman pá pætti sem niðurstöður rannsókna sýna að hafi áhrif á gæðin. Par stendur menntun og hæfni starfsfólks upp úr sem stærsti áhrifapátturinn, en fjölmargar rannsóknir sýna fram á mikilvægi menntunar starfsfólks. Menntun er talin vera sérstaklega áhrifarík hvað varðar samskipti starfsfólks og barna (Barnett og Frede, 2010; Ishimine, 2011; Krieg, Curtis, Hall og Westenberg, 2015; Mims, Scott-Little, Lower, Cassidy og Hesteneso, 2008). Eins og Ólafur Proppé (1992) bendir á er eitt af markmiðum kennaramenntunar að mennta fagmenn. Ragnhildur Bjarnadóttir (2015) bendir jafnframt á að markmið menntunarinnar 
sé að tengja saman starfshæfni og fagmennsku. Samkvæmt (Mennta- og menningarmálaráðuneytið, 2011) á fagmennska kennara að snúast um nemendur par sem markviss samskipti eru höfð í fyrirrúmi til að stuðla að námi og efla hæfni barna. Tekið er fram að pað er ekki eingöngu hlutverk eða skylda kennara að miðla pekkingu til barna heldur verður að gefa börnum tækifæri til að afla sér pekkingar og færni á eigin spýtur, kennarar eiga að örva starfsgleði barna og skapandi hugsun. Til að skilgreina sig sem fagstétt pá parf sérstæða eða sértæka menntun og pekkingu sem hver sem er getur ekki gengið inn í og útfært (Hennum og Østrem, 2016). Samkvæmt Sigurði Kristinssyni (2013) er kunnátta, færni og alúð eitt af pví sem einkennir fagmennsku. Vert er að taka fram að menntun leikskólastjórnenda hefur ekki sỉður áhrif á gæði starfsins pví stuðningur og fagleg leiðsögn peirra hefur áhrif á starfið í heild (Mims o.fl., 2008).

Rannsóknum ber einnig saman um að leik- og námsumhverfi barnanna sé páttur sem hefur áhrif á gæði ístarfinu. Börnum skal tryggt fjölbreytt leik- og námsumhverfi par sem áhugasvið og frumkvæði hvers og eins fær að njóta sín (Barnett og Frede, 2010; Diamond, Barnett, Thomas og Munro, 2007; Krieg o.fl., 2015). Uppeldisfræðileg skráning er aðferð sem hefur verið próuð í Reggio Emilia á Ítalíu til að skrá og meta starf og nám barna og kennara. Aðferðin hefur reynst vel pegar unnið er með áhuga barna. Í slíkri skráningu nýtir kennari gögnin til gagnaöflunar um barnið og áhugasvið pess. Hægt er að líta á skráninguna sem verkfæri fyrir kennara til að gera eigið starf og nám og vinnu barnsins sýnilega. Skráninguna sem kennarar gera er hægt að nýta sem leið að áframhaldandi starfi með barninu eða barnahópnum (Rinaldi, 2006).

Í priðja lagi draga Barnettog Frede (2010) fram að stærð barnahópsins hafiáhrifágæði leikskólastarfsins. Niðurstöður rannsókna sýna að of mörg börn í of litlu rými eykur líkur á árekstrum á milli barna. Pegar barnahóparnir eru of stórir, dregur pað úr tækifærum til að sinna ýmsum námspáttum og tækifærum starfsfólks til að sinna hverju og einu barni. Færri börn í hóp minnkar álag á börnin sjálf og um leið á starfsfólkið. Minni hópar auðvelda börnum að kynnast og eiga í uppbyggilegum samskiptum (Barnett og Frede, 2010; Williams, Sheridan og Pramling-Samuelsson, 2018).

Barnett og Frede (2010) benda einnig á mikilvæga pætti sem tengjast heilsu og vellíðan barna og stuðla að gæðum í leikskólastarfi. Hér á landi hafa verið gerðar rannsóknir sem snúa að vellíðan leikskólabarna. Niðurstöður peirra sýna fram á mikilvægi pess að börnin séu pátttakendur í eigin námi. Einnig kemur fram að börnum líður best pegar pau hafa frelsi til að velja sjálf hvað pau gera og pegar tekið er tillit til peirra sjónarmiða við val á efnivið og viðfangsefnum (Jóhanna Einarsdóttir, 2008; Sara Margrét Ólafsdóttir og Bryndís Garðarsdóttir, 2016).

Síðasti pátturinn sem Barnett og Frede (2010) draga fram sem mikilvægan pátt fyrir gæðastarf í leikskólum er mat á starfinu. Melhuish (2001) bendir pó á að matstæki sem notuð eru í sambandi við gæði leikskólastarfs geti verið nokkuð ólík. Viðmiðin geta verið pað ólík að sami leikskóli komi út með mikil gæði í einu matstæki en lítil gæði í öðru. Til dæmis nær ECERS-kvarðinn (Harms og Clifford, 1980; Harms, Clifford og Cryer, 2005), sem er víða notaður í íslenskum leikskólum, til skipulags starfsins, námsumhverfis og starfshátta en ekki til náms og proska barnanna. Annað dæmi er Eurydice-skýrslan (European Commission/EACEA/Eurydice, 2019) par sem tekin eru saman gögn um nám og umönnun ungra barna í Evrópu og miðað er við fjóra gæðastuðla; hvort allt leikskólastarf fari fram á sama stað en sé ekki skipt upp í til dæmis daggæslu og forskóla, hvort ein stofnun beri ábyrgð á stefnumótun gagnvart öllu leikskólastiginu, hvort gerðar séu kröfur um ákveðna menntun starfsfólks og hvort námskrá sé í gildi fyrir allt leikskólastigið. Niðurstöður skýrslunnar sýna að leikskólastarf á Íslandi er gæðastarf pví Ísland er eitt peirra landa sem uppfyllir öll viðmiðin um gæði sem sett eru fram. Pá er athyglisvert að par kemur fram að íslensk börn eyða að jafnaði meiri tíma í leikskólanum en börn í öðrum löndum sem horft var til. Pá er vert að taka fram að niðurstöður skýrslunnar snúa ekki að innra starfi leikskóla eins og pættirnir sem Barnett og Frede (2010) hafa dregið fram, t.d. leik- og námsumhverfi, tækifærum barna til leiks, hópastærð eða vellíðan barna. Pá er hlutfall menntaðs starfsfólks ekki skoðað í skýrslunni, aðeins að gerðar séu kröfur um menntun pess. 


\section{Skipulag og áherslur í leikskólastarfi}

Skipulag leikskólastarfs getur verið nokkuð ólíkt á milli leikskóla pó svo að öllum leikskólum beri að starfa samkvæmt lögum um leikskóla nr. 90/2008 og (Mennta- og menningarmálaráðuneytið, 2011). Skiptar skoðanir eru á hvað beri að leggja áherslu á í skipulaginu, og eins og Wood (2013) bendir á telja sumir að dagskipulag í starfinu geti orðið stjórntæki leikskólakennara par sem peirra vald tekur yfir réttindi barna. Mikilvægt sé að taka tillit til ólíkra parfa og áhugasviðs barna pegar leikskólastarf er skipulagt og bjóða upp á töluverðan sveigjanleika. Skiptar skoðanir eru pó á hvar megináherslan eigi að liggja og hefur meðal annars verið bent á að með pví að skilgreina leik sem ánægjulegan og sjálfsprottinn, sé dregið úr mikilvægi hans sem námsleiðar (Bodrova og Leong, 2007; Wood, 2013). Aðrir benda á að pegar of mikil áhersla er á leikinn sem námsleið, sé dregið úr ánægjuáhrifum sem honum fylgja (t.d. Lillemyr, 2009, 2013). Prátt fyrir pessa togstreitu virðist vera samkomulag um að gæta purfi jafnvægis parna á milli. Til dæmis hefur Wood (2013) sett fram líkan (sjá Mynd 1) sem sýnir hvernig megi gæta jafnvægis milli verkefna sem stýrt er af leikskólakennurum og leiks sem er sjálfsprottinn hjá börnum. Hún telur að pannig sé báðum sjónarmiðum mætt, ánægjan sem leikurinn veitir börnum fær að njóta sín og leikskólakennarar geta komið námsmarkmiðum inn í námsumhverfið án pess pó að stýra leiknum. Í líkaninu er hlutverki fullorðinna gerð skil par sem kemur fram að peir skipuleggi leik- og námsumhverfið, skipuleggi viðfangsefni og eigið hlutverk, geri athuganir og ígrundi og meti starfið. Í líkaninu er einnig lögð áhersla á að með sveigjanleika í skipulaginu fái áhugi barnanna að ráđa ferðinni, pau hafi nægan tíma og rými til að próa leik sinn og dýpka sig í pví sem pau eru að fást við.

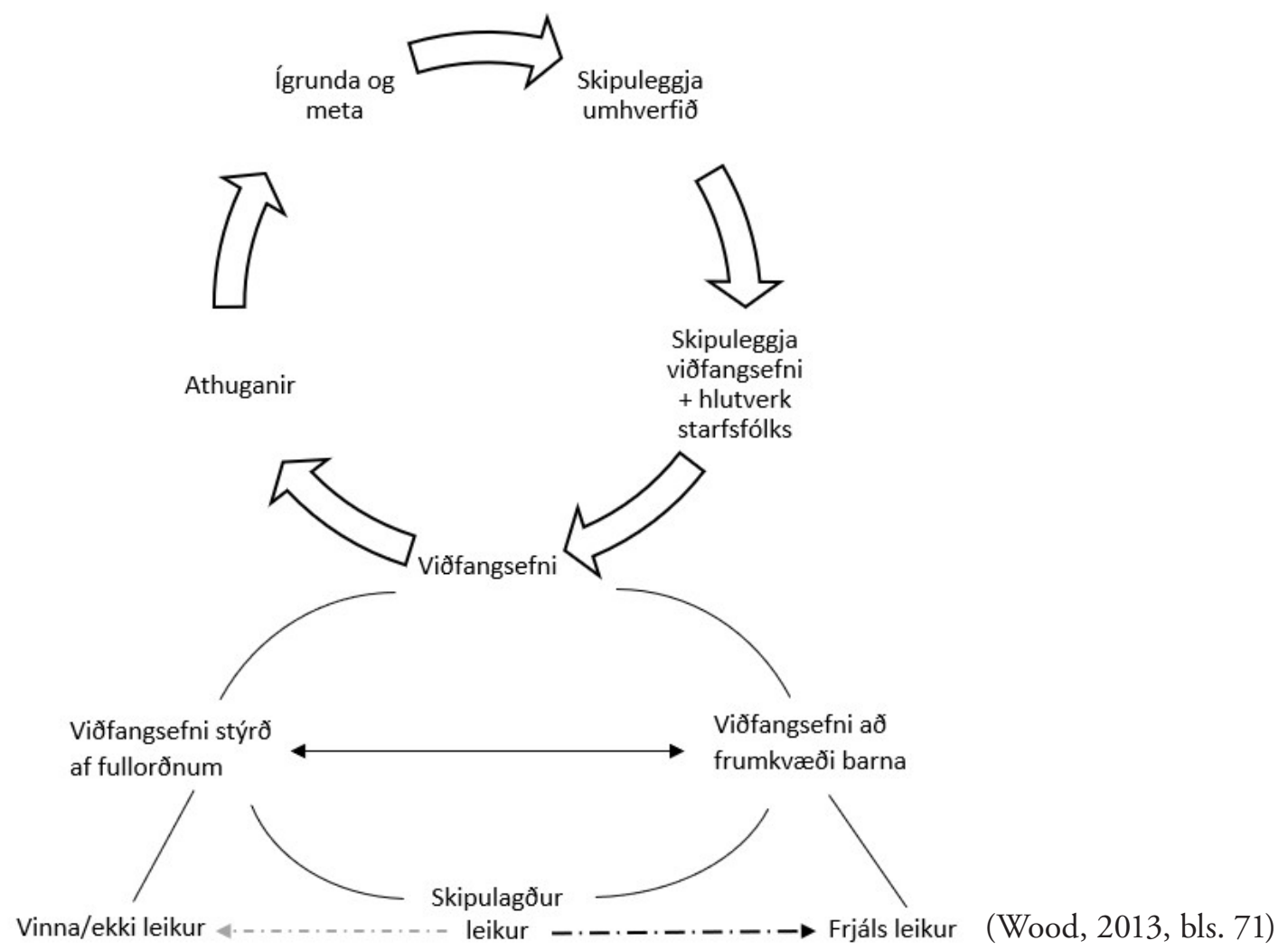

Mynd 1. Líkan fyrir sampættingu námskráa og kennslufræði leikskóla.

Eftir pví sem börn eldast og proskast purfa pau lengri tíma til að próa leik sinn pví peir verða flóknari. Pá reynist vel að tryggja samfellu í náminu, frá einum degi til annars, pannig að börnin hafi tækifæri til að halda áfram með verkefni sín og leiki (Wood, 2013). 


\section{Nám í gegnum leik}

Samkvæmt (Mennta- og menningarmálaráðuneytið, 2011) á að leggja áherslu á nám í gegnum leik í leikskólastarfi enda sýnir fjöldi rannsókna fram á að börn á leikskólaaldri læra best í gegnum leik (Dockett, Lillemyr og Perry, 2013; Lillemyr, 2013). Jafnframt hefur verið sýnt fram á að nám í gegnum leik hefur jákvæð áhrif á formlegra nám seinna meir á lífsleiðinni (Sammons o.fl., 2004; Sylva o.fl., 2004; Taylor og Boyer, 2020). Leikur og nám voru lengi aðskilin hugtök en á síðustu árum hafa fræðimenn fjallað um að leikur og nám eru nátengd fyrirbæri og útskýrt hvernig pau fléttast saman í menntun ungra barna, pannig að börn læri í gegnum leikinn (Pramling-Samuelsson og Pramling, 2013).

Mikilvægt er að leikurinn sé sjálfsprottinn hjá börnunum og byggi á áhugahvöt peirra. Í gegnum leikinn prófa pau sig áfram í samskiptum og máta sig við hlutverk sem pau upplifa í raunveruleikanum. Vygotsky (1978) sagði að barn væri höfðinu hærra í leik, vegna pess að par gæti pað gert meira en í raunveruleikanum. Hann benti á að í leiknum væri barnið óhrætt við að prófa sig áfram og gera mistök vegna pess að leikurinn væri óháður utanaðkomandi reglum og pátttakendur réðu ferðinni. Ýmsir fræðimenn hafa byggt á hugmyndum Vygotskys og próað pær enn lengra (sjá t.d. Bruce, 2004; Smidt, 2007; Wood, 2013). Par er áhersla á að nám fari fram í félagslegu samhengi par sem stuðningur frá hæfari aðila gegnir lykilhlutverki. Pá spilar hlutverk kennara stóran sess í námi ungra barna og mikilvægt að kennarar átti sig á hversu mikil áhrif peir geta haft á hvern einstakling, meðal annars með pví að veita peim tækifæri, tíma og rými til leiks. Fagmennska og hlutverk leikskólakennara felur meðal annars petta í sér.

\section{Аðferðafræði}

Markmið rannsóknarinnar var að varpa ljósi á mat stjórnenda á hvaða áhrif takmarkanir á skólastarfi í fyrstu bylgju COVID-19 höfðu á leik barna í leikskólum og á hlutverk starfsfólks. Jafnframt að skoða hvaða lærdóm mætti draga af reynslunni af takmörkununum. Gögnum var safnað með blönduðum aðferðum (e. mixed methods), með könnunarraðsniði (e. exploratory sequential design) par sem eigindlegum gögnum var fyrst safnað og peim fylgt eftir með viðbótargagnaöflun í megindlegri spurningakönnun (Sigurlína Davíðsdóttir og Anna Ólafsdóttir, 2013). Gögnum var annars vegar safnað í gegnum einstaklingsviðtöl við leikskólastjóra og deildarstjóra. Viðtölin voru tekin í gegnum fjarfundarbúnaðinn Zoom í apríl 2020, á meðan fyrsta bylgja COVID-19 stóð yfir. Vísbendingar úr frumniðurstöðum urðu til pess að send var út spurningakönnun til pess að fá meiri breidd í svörun. Gögnum var pví hins vegar safnað með spurningakönnun var pví send út 15. júní 2020, eftir að fyrstu bylgju lauk. Úrvinnsla gagna úr spurningakönnuninni fór fram í SPSS (útgáfa 26).

\section{Gagnaöflun og pátttakendur}

Pátttakendur í viðtölum voru fjórir leikskólastjórar og fjórir deildarstjórar. Alls voru pví tekin 8 einstaklingsviðtöl sem stóðu yfir í 15 til 65 mínútur. Pátttakendur voru valdir eftir hentugleika út frá aðgengi rannsakenda að peim, p.e. rannsakendur pekktu lítillega til pátttakenda og bakgrunns peirra. Pátttakendur komu frá sex ólíkum sveitarfélögum og enginn peirra starfaði í sama leikskóla. Óskað var eftir pátttöku með pví að senda út tölvupósta par sem markmið rannsóknarinnar var útskýrt. Allir sem fengu tölvupósta sampykktu pátttöku, pannig að ekki purfti að leita til annarra aðila sem féllu undir viðmiðin. Viðtölin voru hálfopin. Pátttakendur voru beðnir um að lýsa hvaða áhrif takmarkanirnar hefðu haft á starfið í peirra leikskóla og hvað hefði helst breyst frá hefðbundnu leikskólastarfi. Sérstaklega var spurt um áhrifin á leik barnanna og hlutverk starfsfólks. Pá var spurt hvaða lærdóm pátttakendur teldu að draga mætti af reynslunni af fyrstu bylgju COVID-19 í tengslum við leikskólastarf og hvort peir teldu að sú reynsla hefði langtímaáhrif.

Spurningakönnunin var send út á netföng 248 leikskóla um land allt, og leikskólastjórar beðnir að svara henni. Ekki var áætlaður ákveðinn svartími. Forritið Qualtrics var notað til pess að senda 
út könnunina. Alls bárust svör frá 172 stjórnendum leikskóla fyrir hönd leikskólanna eða 69\% peirra sem fengu könnun senda svöruðu henni. Pátttakendur í spurningakönnuninni voru beðnir að tilgreina hvaða stöðu peir gegndu við leikskólann. Alls gegndu 134 stöðu leikskólastjóra, 33 aðstoðarleikskólastjóra, sex störfuðu sem deildarstjóri, verkefnastjóri eða kennsluráðgjafi og einn svaraði sem staðgengill leikskólastjóra. Í könnuninni voru bæði lokaðar og opnar spurningar sem byggðu á frumniðurstöðum úr viðtölunum. Spurt var um hvernig takmarkanirnar voru útfærðar og hvaða áhrif pær hefðu haft á skipulag starfsins. Einnig var spurt út í áhrif peirra á leik barna og hlutverk starfsfólks. Pá var spurt hvort pátttakendur teldu að COVID-19 myndi breyta einhverju fyrir leikskólastarf til lengri tíma litið og hvort pað mætti draga einhvern lærdóm um leikskólastarf af reynslunni.

\section{Úrvinnsla gagna}

Viðtölin voru hljóðrituð og afrituð. Við úrvinnslu gagna úr viðtölum og spurningakönnun var byrjað á að kóða gögnin út frá rannsóknarspurningum (Braun og Clarke, 2013). Áherslan var pví lögð á að skoða hvaða áhrif takmarkanirnar höfðu á leik barna, hlutverk starfsfólks og hvort draga mætti einhvern lærdóm af pessari reynslu. Í pessari rannsókn voru gögnin skoðuð út frá fræðum um gæði í leikskólastarfi, skipulag leikskólastarfs, leikinn sem námsleið og hlutverk leikskólakennara (Barnett og Frede, 2010; Dockett o.fl., 2013; Wood, 2013). Sömu pemu birtust í gögnunum varðandi áhrif takmarkana á leik barna og á hlutverk starfsfólks, p.e. auknar gæðastundir í leik og starfi, aukin velliððan í daglegu starfi, áhrif takmörkunar leikefnis, söknuður og einmanaleiki. Niðurstöður verða settar fram út frá pessum pemum.

\section{Niðurstöður}

Í pessari rannsókn var markmiðið að varpa ljósi á sýn stjórnenda í leikskólum á áhrif takmarkana á skólahald vegna fyrstu bylgju COVID-19. Sjónum er beint að áhrifum á leik barna og hlutverk starfsfólks, og jafnframt hvort stjórnendur telja að draga megi einhvern lærdóm af reynslunni af takmörkunum. Niðurstöðurnar verða kynntar út frá peim pemum sem birtust í gögnunum en fyrst verður gerð grein fyrir niðurstöðum varðandi aðstæður í leikskólunum meðan á takmörkunum stóð, par sem pað eru mikilvægar bakgrunnsupplýsingar. İ lokin verða niðurstöðurnar dregnar saman og rýnt í pann lærdóm sem stjórnendurnir töldu að draga mætti af pessari reynslu. Í spurningakönnuninni var spurt hvort leikskólinn hefði verið opinn meðan á takmörkunum á skólahaldi stóð vegna fyrstu bylgju COVID-19 faraldursins. Í svörum stjórnenda kom fram að 87\% leikskólanna voru opnir allan tímann meðan á takmörkunum stóð, 12,5\% leikskólanna voru lokaðir hluta tímans og aðeins 1 leikskóli var lokaður allan tímann. Spurt var hvort starfsemi leikskólans hefði verið skert á pessu tímabili, með fækkun viðverudaga, styttingu viðverutíma eða pess háttar. 215 stjórnendur svöruðu peirri spurningu og í svörum peirra kemur fram að í 104 leikskólum var viðverudögum barnanna fækkað en í 81 leikskóla var viðverutími styttur. Par af var bæði viðverudögum fækkað og viðverutími styttur í 48 leikskólum. Í 17 leikskólum var starfsemin ekki skert.

Einnig var spurt hvort mæting barnanna hefði versnað eða batnað meðan á takmörkunum stóð. Mikill meirihluti taldi mætinguna ekki hafa breyst en pó voru um $25 \%$ sem sögðu að mæting barnanna hefði versnað frekar mikið og um 53\% töldu að mæting barna af erlendum uppruna hefði versnað frekar eða mjög mikið. Spurt var út í mætingarhlutfall barna á meðan leikskólinn var opinn. Aðeins um 10\% barna voru með mætingarhlutfall undir 40\%. Algengasta mætingarhlutfallið var $40-60 \%$.

\section{Auknar gæðastundir í leik og starfi}

Niðurstöðurnar sýna að stjórnendur töldu að áhrif takmarkana á leikskólastarfi í fyrstu bylgju COVID-19 hefðu meðal annars birst í auknum gæðum í leik barna og starfi leikskólastarfsfólks. Spurt var sérstaklega um hópastærð og hvort færri börn hefðu verið í hverju rými eða jafnmörg og 
áđur. Í 138 leikskólum voru færri börn í hverju rými en áður en takmörkun á skólahaldi gekk í garð, 17 stjórnendur sögðu börnin jafnmörg í hverju rými og ádur, en hvergi voru fleiri börn í hverju rými en ádur. Petta virtist skipta sköpum varðandi aukin gæði sem stjórnendur upplifðu pví pegar spurt var út í áhrif fækkunar í barnahópum í hverju rými, mátu stjórnendur pað svo að fækkun í hópum hefði haft mjög mikil eða frekar mikil áhrif á leik barnanna í $61 \%$ tilvika. Af peim töldu rúmlega $33 \%$ fækkunina hafa mjög mikil áhrif á leikinn.

\section{Gaðastundir i leik barna}

Pátttakendum í spurningakönnuninni gafst kostur á að lýsa með nokkrum orðum hvaða áhrif fækkun í hópum hafði á leikinn og bárust 92 svör. Par kom fram að stjórnendur töldu að börnin hefðu notið sín betur í leik, leikurinn varð dýpri pví börnin fengu tíma og rými til að próa hann. Einn stjórnandinn orðaði upplifun sína af fækkun barna í rýmum pannig:

Betri leikur og einbeiting. Börn sem hafa átt erfitt með að stöðva leik náðu að leika sér og ný félagatengsl mynduðust. Miklu meiri ró í leiknum og meiri yfirvegun í hópunum. Fleiri börn fóru að njóta sín betur.

Niðurstöður úr viðtölunum eru í takt við niðurstöður könnunarinnar pví viðmælendur lögðu áherslu á að meðan á takmörkunum stóð fengu börnin meira frelsi og rými til leiks og að pví fylgdi tækifæri til að próa og dýpka leikinn.

Í viðtölunum kom einnig fram að stjórnendur upplifðu að börnin hefðu meiri áhrif á hvað pau gerðu í leikskólanum meðan á takmörkunum stóð og að starfsfólkið gæti betur mætt pörfum peirra. Einn deildarstjóranna sagði:

... pau geta haft meiri skoðun á pví hvað pau vilja gera. Eins og petta, „mig langar að gera eitthvað skemmtilegt" og pá hefur maður tækifæri til pess að hlusta á pað og segja bara „já, hvað langar pig að gera, hvað finnst pér skemmtilegt?“ Eitthvað svona í staðinn fyrir að vera alltaf, „pessi hópur parf að gera petta í dag til pess að uppfylla petta“ og svona alls konar eitthvað.

\section{Geði i starfi leikskólastarfsfólks}

Niðurstöðurnar sýna jafnframt að stjórnendur töldu að takmarkanirnar hefðu haft áhrif á hlutverk starfsfólks pannig að gæði starfsins jukust. Par virtust tveir pættir skipta mestu máli; einfaldara dagskipulag og færri börn í hverju leikrými. Petta leiddi meðal annars til pess að starfsfólkið hafði aukin tækifæri til að taka pátt í leik barna. Petta kom til dæmis fram hjá einum stjórnanda: „Starfið var minna skipulagt pannig að frjálsi leikurinn fékk meiri tíma en áður og starfsfólkið gat gefið sér meiri tíma til pátttöku í leiknum." Meirihluti stjórnenda, eða 55 af 94, svaraði að starfsfólk næði betur að sinna hverju barni og að starfið hefði orðið yfirvegaðra. Einnig nefndu nokkrir stjórnendur að starfsfólk talaði um að pað væri auðveldara að sinna hverju og einu barni par sem hefðbundið dagskipulag féll nánast niður. Í viðtölunum sagði einn deildarstjóri:

Ég myndi frekar vilja starfa alla jafna með 11 börn og 2 kennara heldur en 23 börn með 4 kennara eða 3-4 kennara. Ég held að við náum að sinna í rauninni hverju og einu barni miklu markvissara par sem áreitið er miklu minna.

Með fækkun í barnahópum í hverju rými vildu sumir meina að starfsfólk gæti mætt börnunum af meiri fagmennsku og einnig að starfsfólk pyrfti að sýna meira sjálfstæði í vinnubrögðum par sem deildarstjórar voru ekki alltaf til staðar. Nokkrir nefndu að dregið hefði úr hraða sem einkennir daglegt starf pegar öll börnin eru í húsi. Í viðtali við einn deildarstjóra sagði hann:

... petta hefur líka gefið okkur tækifæri til að gefa í, eins og t.d. með skráningar í pessum aðstæðum ... taka myndir af pessum aðstæðum, af peim börnum og sérstaklega hvað varðar pessi börn sem virðast alltaf vera svolítið til baka og vera undir í leik. 


\section{Aukin vellíðan í daglegu starfi}

Annað pema sem kom fram í niðurstöðunum er aukin vellíðan í daglegu starfi. Stjórnendur upplifðu aukna vellíðan hjá bæði börnum og starfsfólki meðan á takmörkunum stóð. Peir nefndu að andrúmsloftið hefði orðið rólegra, pað dró úr hávaða og áreiti sem leiddi til aukinnar vellíðanar.

\section{Aukin velliðan barna sem birtist i leiknum}

Aftur virðist fjöldi barna í hverju rými hafa mikil áhrif. Petta má til dæmis sjá í svari eins pátttakandans: „Börnin nutu sín betur í minni hópum, höfðu nægt pláss til að leika án pess að trufla aðra í leik og voru ekki bundin af pví að halda sig innan afmarkaðs svæðis. Minna var um árekstra og pústra milli barnanna."

Einnig kom fram að pað væri minna um samkeppni innan barnahópsins og fleiri börn fengju tækifæri til að hafa áhrif í leiknum. Einn pátttakandi skrifaði: „Börn sem yfirleitt láta lítið fyrir sér fara, porðu meira að taka pátt og láta á sér bera." Annar sagðist taka eftir framför í mál- og félagsproska eftir pennan tíma: „... við sáum að peim fór mikið fram í málproska og félagsfærni.“

Viðmælendur í viðtölunum komu einnig inn á petta atriði og sögðust meðal annars hafa upplifað að ný vinasambönd mynduðust og að börn sem héldu sig gjarnan til hlés, blómstruðu og styrktust í pessum aðstæðum. Einn deildarstjórinn lýsti áhrifunum pannig:

Pað er ótrúlega magnað að fylgjast með börnunum hafa allt petta pláss. Pvílíkt svæði sem pau hafa til umráða. Leikurinn peirra blómstrar, krakkar sem eru yfirleitt ekki vanir að leika sér saman eru að tengjast. Börn sem hafa haldið sig til hlés eru kannski alla jafna feimin og ekki mjög framfærin í barnahópnum, pau eru farin að blómstra í pessum aðstæðum, jafnvel taka stjórn í leiknum. Og pau einhvern veginn nýta bara svæðið til að próa leikinn og eru bara um alla deild óhindruð.

\section{Aukin velliðan starfsfólks}

Stjórnendur upplifðu einnig aukna vellíðan hjá starfsfólkinu meðan á takmörkunum stóð. Niðurstöður spurningakönnunarinnar sýna að stjórnendur töldu að starfsfólkinu hefði liðið betur meðan á takmörkunum stóð pví pað varð minna veikt, mætti betur til vinnu og sýndi hvert öðru meira tillit. Auk pess dró úr streitu og álag minnkaði. Einn stjórnandi sagði til dæmis að „hópurinn péttist á einhvern hátt“. Einn deildarstjórinn sagði í viðtali: „Рað var búið að vera mikið af veikindum [áður] og svo er starfsfólkið allt að mæta [núna] ... pað eru engin veikindi búin að vera á starfsfólki.“ I pessu samhengi ræddi einn leikskólastjórinn um að viðhorf hennar til veikinda ættu eftir að breytast og jafnvel mildast á pann hátt að hún ætlaðist ekki til að fólk mætti slappt í vinnu og harkaði af sér.

Minna álag var áberandi í svörum stjórnenda og meðal annars tengt við minni hávaða í umhverfinu. Einn stjórnandi nefndi að hljóðvist î leikskólanum par sem hann starfar væri slök en á pessum tíma pá „féll allt í dúnalogn“. Annar stjórnandi skrifaði að starfsfólk hefði verið minna í að slökkva elda og „pað var ekki verið að flýta sér endalaust eins og vill verða oft“. Einn deildarstjórinn sagði:

Maður er einhvern veginn alltaf að slökkva elda og reyna að vera alls staðar til staðar og allt í einu hefur maður tækifæri til pess að sko bara staldra við og bara einhvern veginn bara fylgjast með. Pað er kannski svona pað sem pessar aðstæður hafa boðið upp á.

Jafnframt veltu sumir fyrir sér hvort átakið í prifum og sótthreinsun hefði einnig haft áhrif á veikindi starfsfólks og barna. Meiri áhersla var á að bæði börn og fullorðnir sem væru með kvefeinkenni væru heima og ekki að koma hálfslöpp í leikskólann, og pað drægi úr smiti á milli manna. 


\section{Takmörkun leikefnis og aukinn prifnaður}

Niðurstöður úr spurningakönnuninni sýna að takmarkanirnar virtust hafa töluverð áhrif á aðgengi barna að efnivið.

Spurt var hvort leikföng hefðu verið fjarlægð af deildum vegna sóttvarna og svöruðu 90\% pví játandi. Pátttakendum var gefinn kostur á að útskýra pað nánar og í peim svörum kom fram að leikföng sem erfitt er að prífa og sótthreinsa hefðu helst verið fjarlægð af deildinni, til dæmis bækur, bangsar og búningar. Einnig kom fram að dregið var úr notkun sameiginlegra rýma á mörgum stöðum, eins og listakrók, til að draga úr sameiginlegum snertiflötum barna deilda á milli. Flestir sögðu að leikföngum væri skipt niður og að pau væru síðan notuð með hvorum barnahóp fyrir sig eða skipt út á milli daga. Einhverjir nefndu að meiri áhersla hefði verið á að nýta skapandi efnivið. Pó kom fram í viðtölunum að petta virtist ekki koma að sök fyrir leik barnanna. Einn deildarstjórinn benti til dæmis á petta: „... prátt fyrir að okkur voru sett pau mörk að takmarka allan efnivið, pað virtist ekki hafa pað mikil áhrif ... pau [börnin] finna bara leiðir." Nokkrir stjórnendur nefndu að sumu starfsfólki hefði ekki fundist pað vera að vinna nógu markvisst faglegt starf, vegna kröfu um að sinna prifum og sótthreinsun á leikföngum og leikrýmum í auknum mæli. Einn stjórnandi taldi að með áherslu á prif og sótthreinsun hefði starfsfólk náð minna að sinna börnunum og annar svaraði að starfið hefði ekki orðið jafn markvisst.

\section{Söknuður, einmanaleiki og einangrun}

Pó svo að stjórnendur hefðu að mestu leyti upplifað áhrif takmarkana á jákvæðan hátt hvað varðar leik barna og hlutverk starfsfólks, pá nefndu peir einnig að börn hefðu upplifað söknuð og starfsfólk einmanaleika á pessu tímabili. Sjálfir upplifðu einhverjir stjórnendur einangrun meðan á takmörkunum stóð.

Stjórnendur nefndu að sum börn söknuðu vina sinna sem voru ekki endilega á sama tíma í leikskólanum og pað var greinilega mörgum börnum erfitt. Einn stjórnandinn taldi pó að petta hefði ekki haft mikil áhrif á börnin en pegar höftum var aflétt sáu pau „hvað börnin urðu glöð að mega blandast og vera saman á útisvæði“.

Í viðtölunum mátti greina að einmanaleiki gerði vart við sig á meðal starfsfólks. Nefndi einn deildarstjórinn að dregið hefði úr beinni samvinnu og skortur hefði verið á faglegu samtali sem hann saknaði. Viðkomandi sagði:

... ég myndi ekki funkera að vera til lengri tíma í svona mikilli einangrun í starfi skilurðu. Og pað er áskorun að vera kannski inni á deildinni sinni allan tímann og ég er að mæta hálf 8 á morgnana og ég er að fara 4 jafnvel hálf 5 . Dagarnir eru langir pó ég sé heima annan hvern dag.

Jafnframt virtust stjórnendur upplifa einangrun í starfi á pessum tíma og svaraði einn stjórnandinn í könnuninni með pessum hætti:

Ég horfi til pessa tíma með blendnar tilfinningar. Mér persónulega fannst ég einangrast sem stjórnandi par sem ég fór ekki inn á deildir heldur hélt mig á skrifstofunni. Ég saknaði bæði barna og kennara mikið.

\section{Samantekt niðurstaðna}

Í rannsókninni voru stjórnendur í leikskólum beðnir um að svara hvaða áhrif peir teldu að fyrsta bylgja COVID-19 hefði á leikskólastarfið til frambúðar og hvaða lærdóm mætti draga af pessu tímabili. 
Helsta lærdóm sem greina mátti í svörum pátttakenda var hvað fjöldi barna í hverju rými gat haft mikil áhrif á leikskólastarfið. Í faraldrinum fundu starfsmenn hversu miklu máli skipti að börnin hefðu nægt rými bæði fyrir leik og starf. Einnig fundu peir að pegar færri börn voru í hverju rými, dró úr álagi bæði fyrir börn og starfsmenn.

Flestir nefndu einnig að mikilvægt væri að draga úr stífu skipulag til að auka gæði starfsins og hægja á peim hraða sem virtist oft einkenna leikskólastarf.

Einhverjir töldu pó að langtímaáhrifin yrðu lítil sem engin. Einn deildarstjórinn sagði:

Ég held að pað komi til með að bara smella aftur í gamla farið ... Рað er allavega búið að bjóða 19 börnum á deildina mína næsta vetur ... pað eru bara kröfur sem sveitarfélagið er að setja manni. Pað vantar leikskólapláss hérna pannig að pað er verið að troða í okkur alveg eins og hægt er.

Samantekt frá einum stjórnanda í könnuninni, um hvaða lærdóm mætti draga af samkomubanninu í tengslum við leikskólastarf, lýsir vel heildarniðurstöðum rannsóknarinnar, par sem hann lagði áherslu á að gæði starfsins hefðu aukist með minna skipulögðu starfi, hann skrifaði: „Við gætum lært svo margt af pessum tíma. Petta var mögnuð „tilraun“ til að sjá gæðastarf verða til við skrítnar aðstæður.“

\section{Umræður}

Markmið pessarar rannsóknar var að skoða áhrif takmarkana á leikskólastarf vegna COVID-19 faraldursins, á leik barna og hlutverk leikskólakennara og annars starfsfólks, út frá sjónarhorni stjórnenda í leikskólum. Jafnframt átti að skoða hvaða lærdóm peir teldu að mætti draga af reynslunni af takmörkununum.

Í pessum kafla verður leitast við að svara eftirfarandi spurningum sem leiddu rannsóknina:

- Hvaða áhrif höfðu takmarkanir í leikskólastarfi vegna fyrstu bylgju COVID-19 á leik barna?

- Hvaða áhrif höfðu takmarkanir í leikskólastarfi vegna fyrstu bylgju COVID-19 á hlutverk leikskólakennara og annars starfsfólks?

- Hvaða lærdóm má draga af reynslunni af takmörkunum í leikskólastarfi vegna fyrstu bylgju COVID-19 og áhrifum peirra á leikskólastarf?

\section{Áhrif takmarkana í leikskólastarfi á leik barna}

Niðurstöðurnar sýna að pátttakendur töldu að gæði starfsins hefðu aukist meðan á takmörkunum stóð. Рað sem hafði par áhrif var að færri börn voru í hverju rými og dagskipulagið varð sveigjanlegra pannig að börnin fengu tíma og rými til að dýpka sig í leiknum og próa hann áfram.

Einnig dró úr árekstrum og börn, sem gjarnan halda sig til hlés og eru feimin, blómstruðu og tóku jafnvel stjórnina í leiknum. Upp úr stendur að pátttakendur upplifðu að börnunum leið almennt betur í leiknum á tímum takmarkana en fyrir pær. Pessar niðurstöður eru í takt við pá grunnhugmyndafræði sem liggur að baki leikskólastarfi m.a. samkvæmt (Mennta- og menningarmálaráðuneytið, 2011) par sem áhersla er lögð á nám í gegnum leik. Fræðimenn hafa par að auki bent á mikilvægi pess að veita börnum rými og tíma til að próa leik sinn pví pannig læra pau og proskast (Vygotsky, 1978; Wood, 2013). Einnig hefur verið bent á mikilvægi pess að hafa jafnvægi og sveigjanleika í skipulaginu (Wood, 2013) og að leik- og námsumhverfi spili stóran sess í að skapa gæðastarf í leikskólum (Barnett og Frede, 2010; Diamond o.fl., 2007; Krieg o.fl., 2015). Niðurstöður rannsóknarinnar styðja pví við pessar áherslur par sem greinilegt var að pátttakendur töldu að með pví að draga úr stífu skipulagi og gefa meira rými til leiks, hefðu börnin notið sín betur og leikurinn orðið dýpri. 
Niðurstöðurnar í tengslum við áhrif á leik barna ríma einnig við pað sem fyrri rannsóknir hafa sýnt fram á varðandi áhrifapætti á gæðastarf í leikskólum. Fyrri rannsóknir hafa t.d. sýnt að stærð barnahóps hefur mikið að segja varðandi gæði í starfinu, líkt og kemur fram í pessari rannsókn. Par hefur verið bent á að of stórir hópar draga úr tækifærum til náms og auka líkur á árekstrum á milli barnanna (Barnett og Frede, 2010; Willams o.fl., 2018) sem er í takt við pað sem pátttakendur pessarar rannsóknar upplifðu.

Pátttakendur upplifðu aukna velliððan barna á tímabilinu, pannig að minna var um árekstra og pústra á milli peirra og pau virtust njóta sín betur í leiknum. Stjórnendur mátu pað meðal annars vera vegna pess að pað voru færri börn í rými og skipulag var sveigjanlegra. Petta er nátengt gæðastarfi í leikskólum pví Barnett og Frede (2010) benda á að pættir sem varði heilsu og vellíðan barna stuðli meðal annars að gæðastarfi. Íslenskar rannsóknir hafa stutt við petta og sýnt fram á mikilvægi pess að veita börnum tækifæri til að hafa áhrif á eigið nám (Jóhanna Einarsdóttir, 2008; Sara Margrét Ólafsdóttir og Bryndís Garðarsdóttir, 2016). Î rannsókninni kom jafnframt fram að pátttakendur töldu börnin geta haft meiri áhrif á pað sem pau gerðu í leikskólanum. Samkvæmt líkani Wood (2013) er einnig lögð áhersla á sveigjanleika svo að áhugi barnanna ráði ferðinni.

Áhugavert er að pátttakendur töldu ekki hafa dregið úr ánægju barnanna í leik pegar aðgengi peirra að leikefni var takmarkað. Einhverjir nefndu að börnin fyndu sjálf leiðir til að viðhalda leik sínum. Pví má segja að leikrýmið sjálft virðist skipta meira máli en leikefnið sem boðið er upp á.

\section{Áhrif takmarkana í leikskólastarfi á hlutverk starfsfólks}

Í niðurstöðunum má greina að stjórnendur töldu að starfið hefði breyst, fólk upplifði að hægt hefði á og pá varð til meira gæðastarf að peirra mati - starf sem einkenndist af fagmennsku, hlustað var á börnin, kennarar upplifðu að peir gætu sinnt hverju barni betur og meðal annars mætt pörfum barna sem annars héldu sig til hlés (Rinaldi, 2006).

Í niðurstöðum kom einnig fram að dregið hefði úr álagi og starfið orðið einfaldara par sem stýrt dagskipulag vék fyrir sveigjanleika og frjálsum leik. Einnig kom fram að færri börn í rými dró úr hávaða. Niðurstöðurnar sýndu að leikskólastarf almennt virtist einkennast af hraða og álagi en meðan á takmörkunum skólahalds stóð hefði frekar verið lögð áhersla á að njóta augnabliksins, veita frið og ró fyrir börn og starfsfólk. Eins og kemur fram í niðurstöðunum pá töldu stjórnendur og starfsmenn að meira svigrúm hefði orðið til fyrir leikinn og um leið möguleika kennara að taka pátt í leiknum eða styðja við hann. Í raun og veru lýstu pátttakendur leikskólastarfi sem helstu fræðimenn telja vera gæðastarf í leikskólum. Eins og Barnett og Frede (2010) segja pá hefur stærð barnahópsins áhrif á gæði í leikskólastarfi. Hættan sem felst í of stórum barnahópum er sú að pá dregur úr tækifærum starfsfólks til að sinna hverju barni. Einnig getur minni barnahópur dregið úr álagi og áreiti bæði fyrir börn og fullorðna (Barnett og Frede, 2010; Williams o.fl., 2018).

Í viðtölunum ræddu stjórnendur um að á meðan takmarkanir stóðu yfir hefði gefist tækifæri til að fylgjast betur með börnum í leik og einn deildarstjóri nefndi að hann hefði fengið tækifæri til að vinna með skráningar. Eins og Barnett og Frede (2010) benda á pá er mat í leikskólastarfi mikilvægt og er uppeldisfræðileg skráning góð leið til að fanga augnablikið og veita innsýn í leikskólastarfið (Rinaldi, 2006).

\section{Lærdómur sem draga má af reynslunni af takmörkunum í leikskólastafi}

Pegar rýnt er í niðurstöðurnar má sjá að flestir pátttakendurnir nefndu mikilvægi pess að huga að leiktækifærum barna og peim gæðastundum sem margir upplifðu pegar dregið var úr hraðanum. Stjórnendur töldu að nýta mætti reynsluna og sáu tækifærin í að draga úr stífu skipulagi, fækka börnum í hverju rými og gefa meiri tíma í leik. Pví má segja að tækifærin sem peir sáu eftir reynsluna falli vel að hugmyndum um gæðastarf í leikskólum (Barnett og Frede, 2010; Wood, 2013). Рað voru 
pó einhverjir sem leyfðu sér að efast um að gæðastarfið sem peir upplifðu á pessum tímum væri komið til að vera. Peir óttuðust að samfélagið færi fljótt aftur inn í hraðann og leikskólinn með.

\section{Lokaorð}

Markmið rannsóknarinnar var að skoða hvaða áhrif takmarkanir á skólahaldi vegna fyrstu bylgju COVID-19 höfðu á leikskólastarf, einkum á leik barna og hlutverk kennara. Jafnframt að skoða hvaða lærdóm mætti draga af reynslunni af pessu tímabili. Áhugavert er að í niðurstöðum kom fram að bæði vellíðan barna og starfsfólks jókst meðan á samkomubanninu stóð, m.a. vegna fækkunar barna í hverju rými og vegna meiri sveigjanleika í dagskipulaginu. Pessi tveir pættir eru meðal peirra sem taldir eru skipta sköpum varðandi gæðastarf í leikskólum. Niðurstöður sýna einnig að pátttakendur rannsóknarinnar töldu að á tímabilinu hefðu gæði starfsins aukist. Niðurstöðurnar benda pví til pess að nú sé mikilvægt fyrir leikskólastjórnendur, rekstraraðila og aðra sem koma að leikskólastarfi, að endurskoða og meta starfið. Ekki er síður mikilvægt að ýta undir umræðu í samfélaginu um leikskólastarf og leggja áherslu á að leikskólabörn purfi rými til leiks og stuðning frá menntuðu starfsfólki til pess að geta notið betur peirrar gæðamenntunar sem gott leikskólastarf býður upp á. Pá má velta fyrir sér ýmsum páttum, eins og: Hvað skiptir máli í námi leikskólabarna? Hvað ættu börn að læra í leikskóla og hvernig? Eru leikskólar landsins komnir út fyrir grunnhugmyndafræði sem liggur að baki starfinu? Hvernig má pá vinna á móti pví, ef staðan er orðin pannig? Pessum spurningum verður ekki svarað hér en niðurstöður rannsóknarinnar sýna fram á að mikilvægt sé að velta peim fyrir sér.

Höfundar telja jafnframt mikilvægt að fylgja niðurstöðum rannsóknarinnar eftir og taka upp práðinn eftir einhvern tíma, pegar COVID-19 faraldurinn verður afstaðinn. Margir áhugaverðir pættir komu fram í rannsókninni sem ekki hefur verið kafað djúpt í hér en mikilvægt er að skoða nánar í framtíðarrannsóknum. Má par einkum nefna stöðu barna af erlendum uppruna og tækifæri peirra til náms í leikskóla, pví að í rannsókninni kom fram að áberandi mest dró úr mætingu peirra á tímabilinu. Pá verður áhugavert að kanna hvað leikskólasamfélagið lærði af reynslunni af takmörkunum á skólahaldi. Hafði reynslan sem birtist m.a. í niðurstöðum pessarar rannsóknar áhrif á leikskólastarf til lengri tíma? Breyttist eitthvað í leikskólastarfi almennt? Var reynslan nýtt til að ýta undir vellíðan og gæðastarf? Рað er áskorun sem leikskólasamfélagið parf að takast á við og verður áhugavert að fylgjast með peirri próun.

\section{COVID-19 and preschool practice: 'A great "experiment" to see quality practice develop in strange situations'}

In Iceland, although all preschools operate in accordance with National Curriculum Guidelines and the Preschool Act (lög um leikskóla nr. 90/2008), their daily schedules can vary depending upon each school's priorities and the teachers' views on how children learn. However, whereas some scholars stress the importance of schedules at preschools that balance the lead activities of teachers and children, others have posited that daily schedules are a means of control used by educators at preschools. In response, and in line with the emphasis on giving children the opportunity to influence their education in the UN Convention of the Rights of the Child, the heightened importance of children's rights has guided preschools in Iceland in reorganizing their practices to consider children's needs and interests.

Against this background, the aim of our study was to illustrate how the limitations in schooling that followed the first wave of COVID-19 influenced preschool practice in Iceland from the perspectives of preschool leaders. Those limitations, going into effect on 16 March and lasting more than 7 weeks until 4 May, were implemented differently in each municipality in Iceland, while nationwide preschool practice was limited across the country. 
Data were gathered by following a mixed-methods approach. On the one hand, eight individual interviews, each lasting 15-65 minutes, with preschool principals and preschool head teachers were conducted in April 2020 during the period of limitations. On the other, preliminary findings from the interviews facilitated a more targeted data collection via a questionnaire distributed shortly after the preschools fully reopened following the period of limitations in June 2020. The questionnaire was sent to 248 preschool principals in Iceland, 172 of whom responded, or a response rate of $69 \%$. Participants were asked whether and, if so, then how the limitations due to COVID-19 had influenced children's play and the role of preschool teachers, as well as whether and, if so, then how those limitations would influence preschool practices in the future and what professionals might learn from the experience.

The findings suggest that the limitations in schooling during the first wave of COVID-19 considerably influenced preschool practices. During interviews and in questionnaires, participants stated that preschool practices were of higher quality during the first wave of COVID-19 than before. This was largely because fewer children attended preschool each day and they were in smaller groups in each play area. In addition, participants believed that the limitations had heightened the well-being of the children and the adults, as well as promoting changes in daily schedules that cultivated a more relaxed atmosphere. For example, this resulted in less sickness within the staff group. Although the limitations also restricted children's access to play- and learning materials, such restrictions did not affect their play or well-being. However, some participants mentioned that because of more focus on cleaning and disinfection, in line with regulations from authorities, some preschool teachers found they had less time to take care of the children.

Beyond that, whereas participants noted new friendships emerging within groups of children during the period of limitations, they also observed that some children missed peers who were no longer in their class group. Finally, some educators reported experiencing loneliness due to being unable to communicate with their peers as freely as they had before the limitations. Altogether, the study makes an important contribution to the preschool community by providing knowledge and understanding as to how the first wave of COVID-19 influenced preschool practices, at least in Iceland, and as to how it may continue to alter such practices in the future. In that light, the findings can also inform further reflections on how practices at preschools are organized and which ones are prioritized.

Key words: COVID-19, preschool practice, play, preschool teachers' role, quality in practice

\section{Um höfunda}

Ingibjörg Ósk Sigurðardóttir (ios@hi.is) er lektor í leikskólafræði við Menntavísindasvið Háskóla Íslands. Rannsóknir hennar hafa einkum fjallað um leikinn, starf leikskólakennara, faglega próun leikskólakennara og ferli starfendarannsókna. Ingibjörg Ósk hefur tekið pátt ýmsum innlendum og erlendum rannsóknarverkefnum um ólík viðfangsefni í tengslum við leikskólastarf, í samstarfi við leikskólakennara sem eru starfandi í leikskólum og við rannsakendur. Ingibjörg Ósk kennir í leikskólakennaranámi við Menntavísindasvið.

Svava Björg Mörk (svavabm@hi.is) er doktorsnemandi og aðjúnkt í leikskólafræði og menntastjórnun við Menntavísindasvið Háskóla Íslands. Rannsóknir hennar hafa einkum fjallað um samstarf hagsmunaaðila í leikskólakennaramenntun, fagmennsku leikskólakennara, leiðsögn leikskólakennaranema og lærdómssamfélag. Svava Björg rannsakar hvernig byggja megi upp samstarfssvæði í leikskólakennaramenntun á Íslandi. Svava Björg kennir í leikskólakennaranámi og stjórnunarnámi við Menntavísindasvið. 


\begin{abstract}
About the authors
Ingibjörg Ósk Sigurðardóttir (ios@hi.is) is an assistant professor in early childhood education at the School of Education, University of Iceland. Her research has been in the field of play, preschool teachers' practice, preschool teachers' professional development and the process of action research. Ingibjörg Ósk has participated in several national and international research projects within different fields in relation to preschool practice, in collaboration with preschool teachers and researchers. Ingibjörg Ósk teaches the preschool teachers' education program at the School of Education.

Svava Björg Mörk (svavabm@hi.is) is a doctoral student and adjunct in early childhood education and educational leadership at the School of Education, University of Iceland. In her research she focuses on collaboration between stakeholders in early childhood education, preschool teachers' professionalism, preschool teacher students' mentoring and learning community. Svava Björg is currently researching how the third space can become a learning arena in preschool teachers' education. Svava Björg teaches in the preschool teachers' education program and education leadership program at the School of Education.
\end{abstract}

\title{
Heimildir
}

Auglýsing nr. 216/2020 um takmörkun á skólastarfi vegna farsóttar.

Barnett, W. S. og Frede, E. (2010). The promise of preschool: Why we need early education for all. American Educator, 34(1), 21-29. Sótt af http://search.ebscohost.com/login.aspx?direct=true\&db=eric\&AN= EJ889144\&site=ehost-live

Bodrova, E. og Leong, D. J. (2007). Tools of the mind: The Vygotskian approach to early childhood education (2. útgáfa). New Jersey: Pearson.

Braun, V., og Clark, V. (2013). Successful qualitative research: A practical guide for beginners. London: Sage.

Bruce, T. (2004). Developing learning in early childhood. London: Paul Chapman.

Campbell, F. A., Pungello, E. P., Burchinal, M., Kainz, K., Pan, Y., Wasik, B. H., . . Ramey, C. T. (2012). Adult outcomes as a function of an early childhood educational program: An abecedarian project follow-up. Developmental Psychology, 48(4), 1033-1043. doi:10.1037/a0026644

Diamond, A., Barnett, W. S., Thomas, J. og Munro, S. (2007). Preschool program improves cognitive control. Science, 318(5855), 1387-1388. doi:10.1126/science.1151148

Dockett, S., Lillemyr, O. F. og Perry, B. (2013). Play and learning in early years education: International perspectives. Í O. F. Lillemyr, S. Dockett og B. Perry (ritstjórar), Varied perspectives on play and learning: Theory and research on early years education (bls. 1-8). Charlotte: Information Age Publishing.

European Commission/EACEA/Eurydice. (2019). Key data on early childhood education and care in Europe2019 Edition. Eurydice report. Luxembourg: Publications Office of the European Union.

Harms, T. og Clifford, R. (1980). Early childhood environment rating scale. New York: Teachers College Press.

Harms, T., Clifford, R. og Cryer, D. (2005). Early childhood environment rating scale: Revised edition. New York: Teachers College, Columbia University.

Hennum, B. A. og Østrem, S. (2016). Barnehagelareren som profesjonsutøver [Leikskólakennarinn sem fagmaður]. Oslo: Cappelen Damm.

Ishimine, K. (2011). Quality in early childhood education and care: A case study of disadvantage. Australian Educational Researcher, 38(3), 257-274. doi:10.1007/s13384-011-0028-6

Jóhanna Einarsdóttir. (2008). Children's and parents' perspectives on the purposes of playschool in Iceland. International Journal of Educational Research, 47(5), 283-291. doi:10.1016/j.ijer.2008.12.007 
Krieg, S., Curtis, D., Hall, L. og Westenberg, L. (2015). Access, quality and equity in early childhood education and care: A South Australian study. Australian Journal of Education, 59(2), 119-132. doi: $10.1177 / 0004944115588789$

Lillemyr, O. F. (2009). Taking play seriously: Children and play in early childhood education. An exciting challenge. Charlotte: Information Age Publishing.

Lillemyr, O. F. (2013). Perspectives on play and learning, and their relation to motivation. Í O. F. Lillemyr, S. Dockett og B. Perry (ritstjórar), Varied perspectives on play and learning: Theory and research on early years education (bls. 21-36). Charlotte: Information Age Publishing.

Lög um leikskóla nr. 90/2008.

Melhuish, E. C. (2001). The quest for quality in early day care and preschool experience continues. International Journal of Behavioral Development, 25(1), 1-6. doi:10.1080/01650250042000492

Mennta- og menningarmálaráðuneytið. (2011). Aðalnámskrá leikskóla 2011. Sótt af https://www.stjornarradid. is/media/menntamalaraduneyti-media/media/forsidumyndir/lokadrog-leiksk_vefur.pdf

Mims, S. U., Scott-Little, C., Lower, J. K., Cassidy, D. J. og Hestenes, L. L. (2008). Education level and stability as it relates to early childhood classroom quality: A survey of early childhood program directors and teachers. Journal of Research in Childhood Education, 23(2), 227-237.

Ólafur Proppé. (1992). Kennarafræði, fagmennska og skólastarf. Uppeldi og menntun, 1(1), 223-231.

Pramling-Samuelsson, I. og Pramling, N. (2103). Winnie-the-Pooh sat in a three, or did he? A contemporary notion of early childhood beyond teaching and free play. Í O. F. Lillemyr, S. Dockett og B. Perry (ritstjórar), Varied perspectives on play and learning: Theory and research on early years education (bls. 9-20). Charlotte: Information Age Publishing.

Ragnhildur Bjarnadóttir. (2015). Leiðsögn: Lykill að starfsmenntun og skólapróun. Reykjavík: Háskólaútgáfan.

Rinaldi, C. (2006). In dialogue with Reggio Emilia: Listening, researching and learning. London: Routledge.

Sammons, P., Elliot, K., Sylva, K., Melhuish, E., Siraj-Blatchford, I. og Taggart, B. (2004). The impact of pre-school on young children's cognitive attainments at entry to reception. British Educational Research Journal, 30(5), 691-712.

Sara Margrét Ólafsdóttir og Bryndís Garðarsdóttir. (2016). Vellíðan barna í leikskóla - samstarfsrannsókn. Í Kristín Karlsdóttir og Anna Magnea Hreinsdóttir (ritstjórar), Leikum, larum, lifum: Námssvið leikskóla og grunnpattir menntunar (bls. 31-56). Reykjavík: RannUng og Háskólaútgáfan.

Sheridan, S. og Pramling-Samuelsson, I. (2013). Preschool a source for young children's learning and well-being. International Journal of Early Years Education, 21(2-3), 207-222. doi:10.1080/09669760.2013.832948

Sigurður Kristinsson (2013). Að verðskulda traust: Um siðferðilegan grunn fagmennsku og starf kennara. Í R. Sigpórsson, R. Eggertsdottir,og G. H. Frimannsson, Fagmennska i skólastarfi: Skrifað til heiðurs Trausta Porsteinssyni (bls. 237-255). Reykjavík: Háskólaútgáfan

Sigurlína Davíðsdóttir og Anna Ólafsdóttir. (2013). Notkun blandaðra aðferða í rannsóknum. Í Sigríður Halldórsdóttir (ritstjóri), Handbók i aðferðafraði rannsókna (bls. 393-402). Akureyri: Háskólinn á Akureyri.

Smidt, S. (2007). A guide to early years practice (3. útgáfa). London: Routledge.

Stjórnarráð Íslands. (2020, 13. mars). Tillögur sóttvarnalæknis til heilbrigðisráðherra. Sótt af https://www. stjornarradid.is/library/04-raduneytin/Heilbrigdisraduneytid/ymsar-skrar/Till\%c3\%b6gur\%20s\%c3\%b3t tvarnal\%c3\%a6knis\%20til\%20heilbrig\%c3\%b0isr\%c3\%a1\%c3\%b0herra.pdf

Sylva, K., Melhuish, E., Sammons, P., Siraj-Blatchford, I., Taggart, B. og Elliot, K. (2004). The effective provision of pre-school education (EPPE) project: Findings from pre-school to end of key stage 1. Sótt af https://ro.uow. edu.au/cgi/viewcontent.cgi?article $=3155 \&$ context=sspapers

Taylor, M. E. og Boyer, W. (2020). Play-based learning: Evidence-based research to improve children's learning experiences in the kindergarten classroom. Early Childhood Education Journal, 48,127-133. https://link. springer.com/article/10.1007/s10643-019-00989-7

Vandell, D. L. og Wolfe, B. (2000). Child care quality: Does it matter and does it need to be improved? Institute for Research on Poverty, Special report no. 78. doi:10.1037/e305862003-001 
Vygotsky, L. S. (1978). Mind in society: The development of higher psychological processes. Cambridge, MA: Harvard University.

Williams, P., Sheridan, S. og Pramling-Samuelsson, I. (2018). A perspective of group size on children's conditions for wellbeing, learning and development in preschool. Scandinavian Journal of Educational Research, 63(5), 696-711. doi:10.1080/00313831.2018.1434823

Wood, E. (2013). Play, learning and the early childhood curriculum (3. útgáfa). London: Sage.

Ingibjörg Ósk Sigurðardóttir og Svava Björg Mörk. (2020).

Kófið og leikskólinn: „Đetta var mögnuð „tilraun“ til að sjá gæðastarf verða til við skrítnar aðstæður“

Netla - Veftímarit um uppeldi og menntun: Sérrit 2020 - Menntakerfi og heimili á tímum COVID-19

Sótt af http://netla.hi.is/serrit/2020/menntakerfi_heimili_covid19/03.pdf

DOI: https://doi.org/10.24270/serritnetla.2020.20 